\title{
School Management Solutions to Students' Performance Forewarning: An Institutional Research of a Senior High School in Taiwan
}

\author{
Shu-Fang Lin, Hung-Chang Chang, Chi-Tung Chen, and Ching-Ling Wu
}

\begin{abstract}
This study explores the content of Institutional Research and its application on school management focused on students' learning achievement and behavioral performance forewarning. We conducted a case study of a senior high school in Taiwan to explore the empirical application of IR results on finding school management solutions. On the ground of a three-aspect literature review of senior high school institutional work, IR, and school forewarning systems, the study demonstrated how to employ IR concepts and school forewarning systems to analyze the student data of learning achievement and behavioral performance in a senior high school beyond student evaluation. Based on the aforementioned empirical results of IR, the study delved into meanings behind numbers, and attempted to find possible solutions to problems.
\end{abstract}

Index Terms-Institutional research (IR), school management, senior high school, forewarning.

\section{INTRODUCTION}

Due to the demands of external accountability as well as institutional interest in postsecondary improvement, assessment of student learning has become deeply embedded in institutional policies and practices. Especially in the past 15 years, higher education officials have witnessed a growing body of literature on the assessment of learning and institutional policies that can support assessment. These studies show that assessment allows institutions to be accountable and can improve educational performance [1]-[3]. Accordingly, at school management solutions, we are focused on empowering schools to improve processes, strengthen understanding, enhance services and ultimately better serve students. Students' learning achievement and their behavioral performance are crucial indicators both to their school life adaptation and school educational quality. Accordingly, students' learning achievement and their behavioral performance would be worthy of becoming a focus of school institutional work and need stressed by school leaders or administrators. In Taiwan, students' learning achievement and their behavioral performance will mostly transfer into scores composed of numbers or ranking. The meanings hidden behind the numbers are quite important and meaningful to students, parents, teachers and especially school administrators. To find out the developmental trends of the above meaningful numbers and intervene timely are

Manuscript received July 2, 2018; revised November 4, 2018.

The authors are with National Chi Nan University Taiwan, Taiwan (e-mail: shoufanglin@yahoo.com.tw,

chitung@ncnu.edu.tw, clwu@ncnu.edu.tw). both very important to keep students stably remaining in schools. This timely intervention will certainly follow up effective forewarning system. That is to say, forewarning plays an important role to remain students in their campus lives.

In this study, we try to explore the content of Institutional Research (IR) and its application on school management focused on students' learning achievement and behavioral performance forewarning. IR was proposed to effectively deal with America Universities' management issues in 1940. Institutional research (IR) professionals, with knowledge of higher education assessment, organizational theory, and research design, have served as collaborators with campus colleagues who may need assistance with survey design, statistical analysis, assessment of a discrete unit's activity and/or broad institutional review [4].

With the application of IR, school affairs including strategies analysis, planning, student recruitment, financial management, instructional quality assurance, students learning achievement assessment, program evaluation, school management efficacy and certificates could possibly be rooted in data science and evidenced base. To solve the students' recruitment difficulties caused by low birth rate, Taiwan Association Institutional Research (TAIR) established in 2016 [5]. Universities in Taiwan try to apply IR to understand their school affairs and try to make decisions or choices based on evidences. They hope to form clever strategies on school management especially on students' recruitment. Although senior high schools in Taiwan face the same tough problems, they fail to take advantage of IR to improve their school management quality due to insufficient professional knowledge and techniques. In such situation, we try to apply a model of IR designed for senior high schools to conduct empirical experiments of IR to practice forewarning system for finding school management solutions which focus on students learning achievement and behavioral performance.

In the other words, based on a three-aspect literature review of senior high school institutional work, IR, and school forewarning systems, the study demonstrated how to employ IR concepts and school forewarning system to analyze student data of learning achievement and behavioral performance in a senior high school. The study asked two research questions namely: (1) how to conduct an empirical IR based on institutional data of a senior high school? (2) how does a senior high school apply the empirical results of IR to practice forewarning system for finding school management solutions? 


\section{LITERATURE REVIEW}

\section{A. Senior High School Institutional Works}

According to Senior High School Education Act of Taiwan, the Article 1 of Chapter I General Principles points out that senior high school education is a continuance of 9-year national education, its ultimate purpose is to strengthen students' mind and body, to develop their potentials, to lay the foundation for academic research as well as professional skill, and to cultivate high-quality citizens with balanced development in five aspects of education. The Article 5 of Chapter II Establishment, Classification, and Evaluation mentions that senior high schools are classified as follows: 1) Regular: the core curriculum provides fundamental subjects to strengthen students' general competencies; 2) Skill-based: the core curriculum provides professional subjects and practicum, which encompasses practical skills and cooperative education, to strengthen students' professional skills and occupational ability. 3) Comprehensive: the curriculum provides fundamental subjects, professional subjects and practicum that guide students to appropriate channels; 4) Specialty-based: the core curriculum features a specific subject or field to target students with a special aptitude [6].

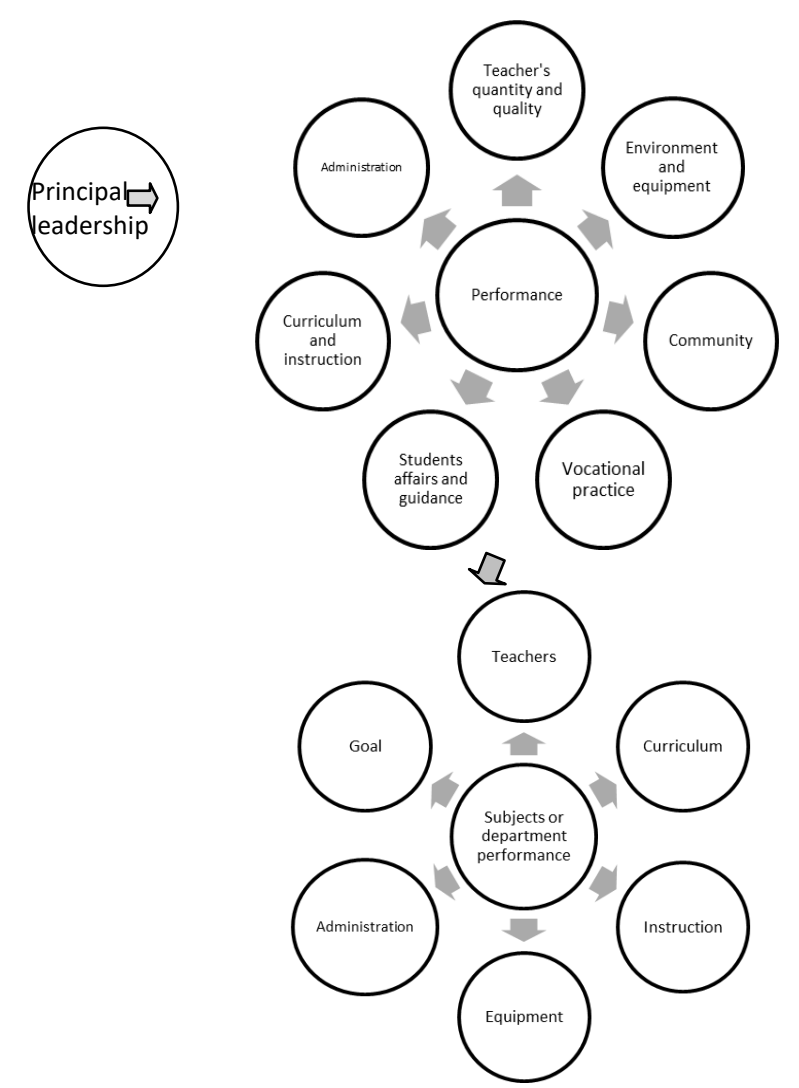

Fig. 1. Taiwan's 2015 senior high schools' school evaluation program.

Whatever which classification of senior high school is, daily routine works in a senior high school are quite trivial but well organized. Senior high school institutional works mainly center in instruction and learning, however based on school's philosophy, administration, environment, equipment and so on. According to Taiwan's 2015 senior high schools' school evaluation program, schools need to perform well in the below 8 areas, including (1) the principal's educational philosophy (2) administration and management strategies (3) curriculum and instruction (4) teachers' quantity and quality (5) students' affairs and guidance (6) community (7) environment and equipment (8) practice and consulting / professional departments. All above areas ought to put into practice effectively and efficiently. The structure of school evaluation content is as Fig. 1 shows [7].

The structure of school-evaluation program points out the important tasks for senior high schools. In other words, that means senior high schools need to adopt those tasks or works into their scope of school institutional works. Combining the spirit of Act and the content of school evaluation program, in this study, school institutional works were defined on the basis of Senior High School Education Act and Taiwan's 2015 senior high schools' school evaluation program. It is believed that senior high schools ought to keep the rule of the Act and execute their institutional works exactly to the extent to be good enough as they are evaluated.

\section{B. Institutional Research}

In Taiwan, more and more universities involve themselves in IR works, such as Taiwan Normal University, Sun Yat-sen University, Asia University, Shih Hsin University, University of Kaohsiung, Soochow University and Chang Gung University of Science and Technology. Those universities design their own framework and analysis system of IR and then conduct IR work to respond to school management needs. The main reasons that universities make an effort on IR are very similar. According to Taiwan Normal University for example, institutional research is based on the collection and analysis of objective data. It is used to understand the current situation and problems of schools' operation, and to establish a feedback system. It is the basis for the improvement of school affairs, and among numerous issues, the collection and analysis of student data is much more important. Through the collection and analysis of objective data (such as school status, employment status) and subjective opinions (such as satisfaction, expectation, and evaluation), schools and departments can correct school strategies and practices in response to social changes and student needs. The Ministry of Education has promoted teaching excellence programs to promote higher education institutions in higher education to serve students and serve the community. The quality of the student information analysis system's integration, construction and application is the pursuit of excellent goal for higher education colleges and universities [8].

Making decisions should be less intuitive, more data and evidence based [9]. In 1940, Institutional Research (IR) was proposed to effectively deal with America Universities' management issues. Volkwein thinks that there are three concepts involving IR critical to school management: (1) school affairs reports and strategies analysis; (2) planning, student recruitment, and financial management; (3) quality assurance, learning achievement assessment, program evaluation, efficacy and certificates [10], [11]. Being faced up numerous educational challenges, Taiwan Association for Institutional Research (TAIR) established in the Jan. of 2016 [5]. It is believed that IR concepts and trends will start to 
grow stronger and stronger theoretically and empirically in Taiwan.

In spite of harsh challenges as senior high schools confront; however, much less senior high schools than universities try to apply IR to form evidence-based strategies and decision in lack of IR professional knowledge and skills. In such condition, this study hopes to demonstrate a practical model of decision making grounded on IR and empirical demonstration of forewarning system in a senior high school to pave the way to innovative management of students' performance.

\section{School Forewarning Systems in IR Model}

After literature review and reference to researchers' empirical experience, we proposed an IR model for senior high schools in 2016 [12], [13] as Fig. 2, 3 and 4 show. This IR model divides into three stages including students' enrollment stage (Stage I), school attendance stage (Stage II) and graduates' career development stage (Stage III). In addition, this model contains seven analytic modules of student recruitment analyses, school financial management, learning effect analyses, student guidance, teaching quality analyses, higher education attending ratio analyses and occupation analyses. In this study, we focus on the way and methods of forewarning system works to help schools to keep aware of students' performance in time and intervene if students need after assessment. Fig. 5 shows us the school forewarning systems in this IR model.

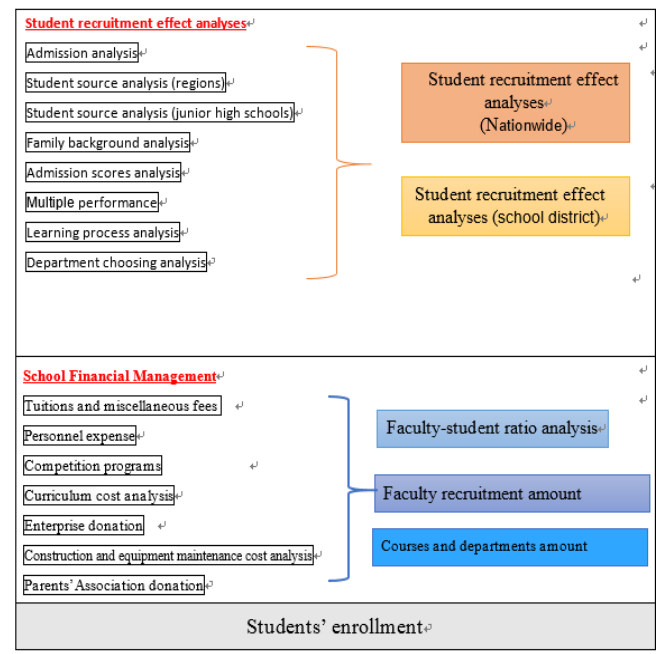

Fig. 2. Stage I: Students' enrollment stage.

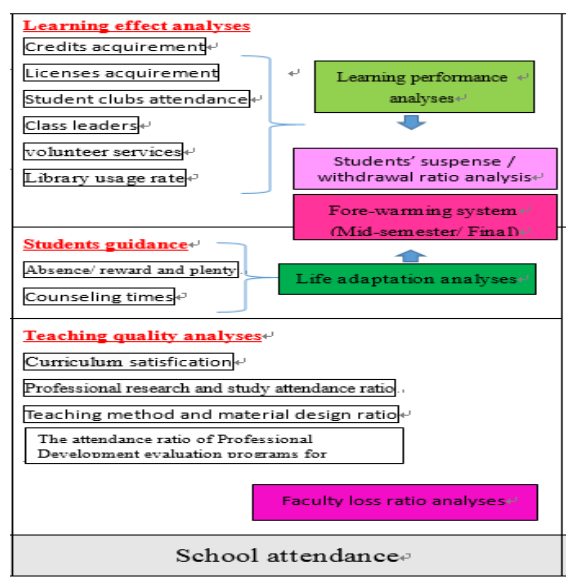

Fig. 3. Stage II: School attendance stage.

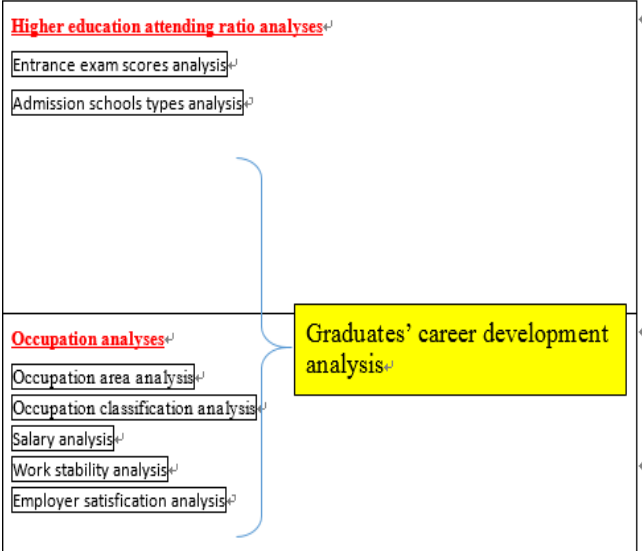

Fig. 4. Stage III: Graduates' career stage.

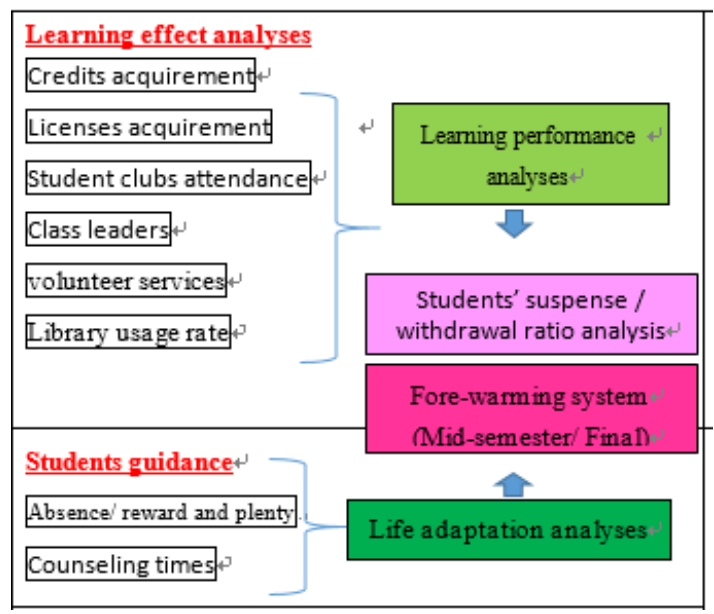

Fig. 5. School forewarning systems in IR model.

\section{Methodology}

We applied an Institutional Research model for senior high schools proposed in 2016 [12], [13]. Based on school affairs of senior high schools, this IR model includes all aspects of school management issues and can be put into investigations thematically. This model can provide evidence-based strategies with the application of BI analytic software to polish senior high schools' management strategies and methods. In this study, we took the forewarning system function for example to demonstrate how to use this IR model to help students, teachers and even administrators take control of and keep pace with students' academic and behavioral performance. Keeping aware of students' performance in time will be beneficial to make necessary adjustment of instructional plans or guidance interventions that students need.

\section{A. Research Method and Process}

In the exploratory stage, researchers conducted literature review, referred to and integrated our empirical experience in senior high schools to understand better on the school affairs of senior high schools. After that, we applied an Institutional Research model we designed and proposed for senior high schools in the demonstration stage to demonstrate how to use the IR model with the example of forewarning system function. In the final amendment stage, we tried to form some strategies and suggestions to improve forewarning systems works in senior high schools. Based on the results of IR experiments, we can produce data-based suggestions or 
strategies for senior high schools' students, teachers and administrators to improve students' academic and behavioral performance. The research method and process were as Fig. 6 shows.

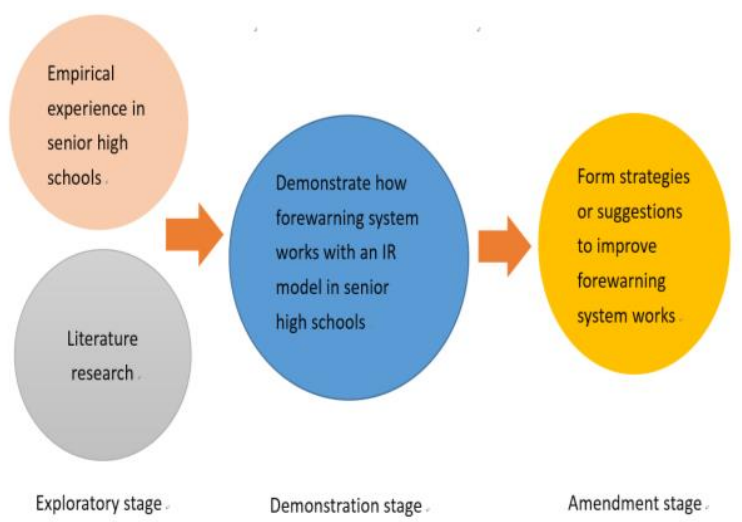

Fig. 6. Research method and procedure.

\section{B. Research Instrument}

Institutional Research is the core concept of this study. In this study, we use BI analytic software "QlikView " as analysis tool and its function is described as follows.

QlikView is a flexible Business Intelligence platform for turning data into knowledge. It promotes unrestricted analysis of application data, helping users make time-saving and accurate decisions. It also brings a whole new level of analysis, insight, and value to existing data stores with user interfaces that are clean, simple, and straightforward [14]. Fig. 7 shows us the structure of BI system.

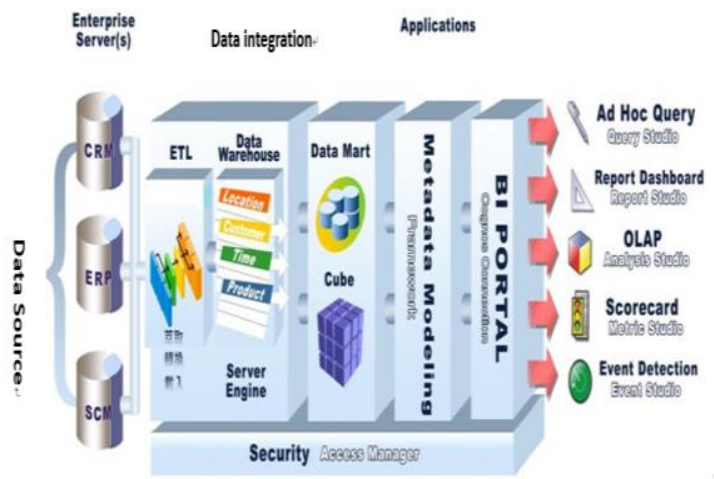

Fig. 7. Business Intelligence structure system (Retrieved from http://www.bilab.pro/bi/_Slides/BI.pptx ) .

\section{RESUlTS AND DisCUSSION}

\section{A. Conduct an Empirical IR Based on Institutional Data} of a Senior High School

An IR based on students' academic and behavioral performance of a senior high school in central Taiwan was conducted to understand better how students perform and the developmental trend. With this understanding, students, teachers and administrators can reorganize their strategies to make progress. Fig. 8, Fig. 9 and Fig. 10, for example, show us the class 302 306' English scores in the past 5 semesters. The Fig. 11 is the statistics and comparisons results of students' leave, lateness and absence in different semesters. Based on various institutional data of a senior high school, IR results could be quite numerous but meaningful to students, teachers, administrators and the principal.

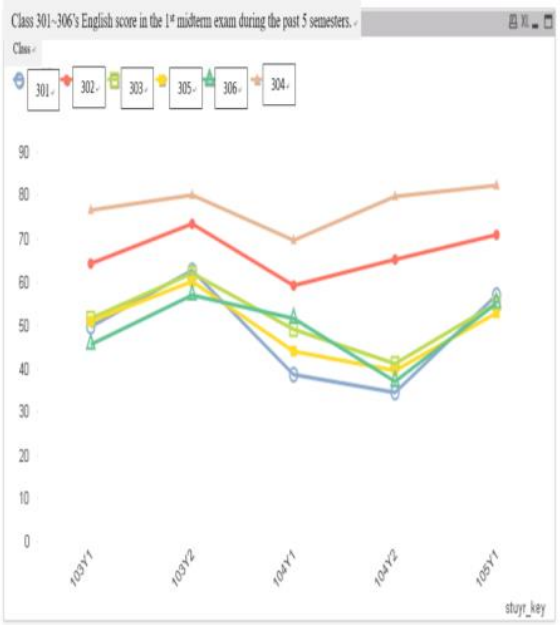

Fig. 8. Class 301 306's English score in the 1st midterm exam during the past 5 semesters.

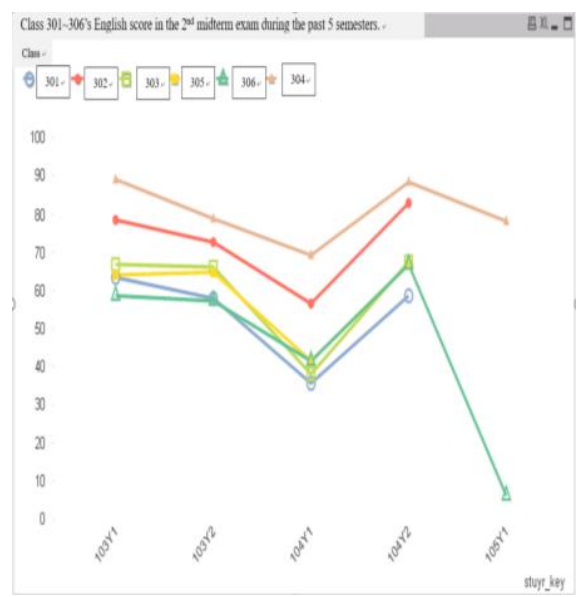

Fig. 9. Class 301 306's English score in the 2nd midterm exam during the past 5 semesters.

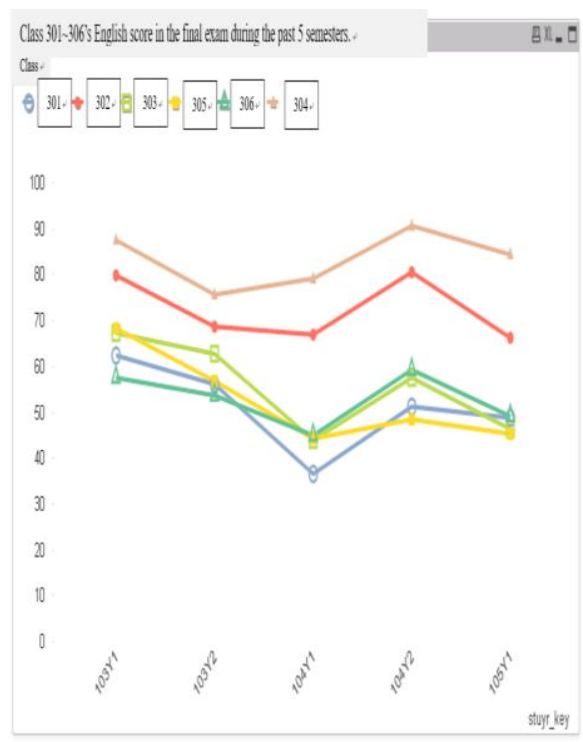

Fig. 10. Class 301 306's English score in the final exam during the past 5 semesters.

B. The Way That a School Applies the Empirical Results of IR to Practice Forewarning System

Based on the results of IR, this school sets its own forewarning regulation about different forewarning types. 
Then, forewarning function is easily to be activated by information systems. The forewarning type and regulation set by this school are presented as Table I; forewarning method is as Table II shows. Fig. 12 to 15 were the simulated forewarning pictures of students' subject scores, class subject average scores, a forewarned student's academic performance on her or his all subjects and students' absence list. With the effort of forewarning works, students, teachers, and administrators in this school can keep pace with the changing trends of students' academic and behavioral performance. Necessary interventions could be possible to take in time to prevent students' worse and worse performance and then help keep students to stay stably in schools.

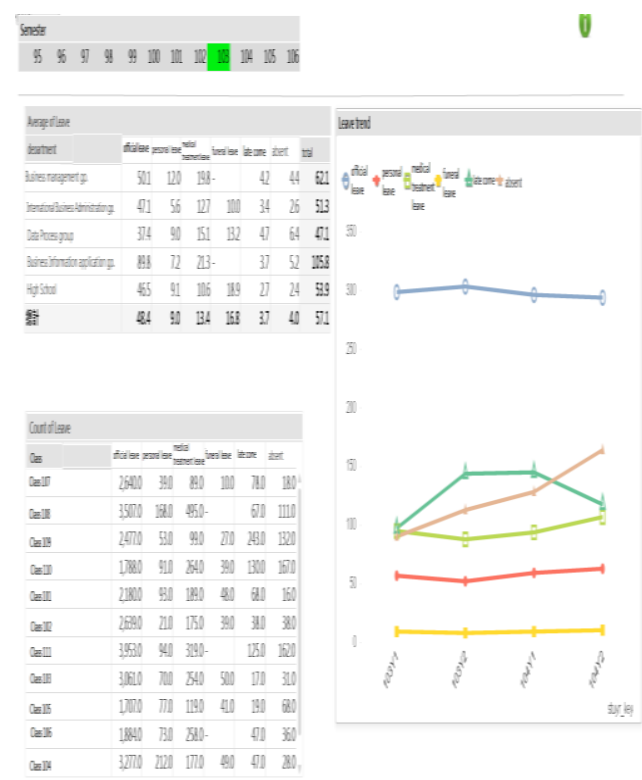

Fig. 11. The statistics and comparisons of students' leave, lateness and absence in different semesters (LIN \& LIN, 2016).

TABLE I: FOREWARNING TYPE AND REGULATION

\begin{tabular}{|c|c|}
\hline $\begin{array}{c}\text { Forewarning } \\
\text { type }\end{array}$ & Regulation \\
\hline $\begin{array}{l}\text { Academic } \\
\text { credit }\end{array}$ & $\begin{array}{l}\text { 1.32 academic credits every semester, if students } \\
\text { get less than } 1 / 2 \text { credits } \\
\text { 2.The } 1^{\text {st }} \text { semester at the first grade of senior high } \\
\text { school: less than } 16 \text { academic credits } \\
\text { 3. The } 2^{\text {nd }} \text { semester at the first grade of senior } \\
\text { high school: less than } 32 \text { academic credits } \\
\text { 4.The } 1^{\text {st }} \text { semester at the second grade of senior } \\
\text { high school: less than } 48 \text { academic credits } \\
\text { 5.The } 2^{\text {nd }} \text { semester at the second grade of senior } \\
\text { high school: less than } 64 \text { academic credits } \\
\text { 6.The } 1^{\text {st }} \text { semester at the third grade of senior } \\
\text { high school: less than } 80 \text { academic credits } \\
\text { 7.The } 2^{\text {nd }} \text { semester at the third grade of senior } \\
\text { high school: less than } 160 \text { academic credits }\end{array}$ \\
\hline Score & $\begin{array}{l}\text { 1.The } 5 \% \text { of students in the class from the last in } \\
\text { the first or second midterm exams will receive } \\
\text { forewarning e-mails. } \\
\text { 2.The mean scores of subjects are below } 50 \\
\text { scores in the first or second midterm exams, } \\
\text { fore-warning e-mails will be sent to subject } \\
\text { teachers. }\end{array}$ \\
\hline $\begin{array}{l}\text { Behavioral } \\
\text { Performance } \\
\text { (Rewarding, } \\
\text { punishment and } \\
\text { absence } \\
\text { conditions) }\end{array}$ & $\begin{array}{l}\text { 1. Students who receive } 18 \text { or } 27 \text { times of } \\
\text { warning for their behavioral performance will } \\
\text { be forewarned. } \\
\text { 2.The hours that students who are absent, late, } \\
\text { early leaving from class are more than } 21 \text {. } \\
\text { They will be forewarned. }\end{array}$ \\
\hline
\end{tabular}

TABLE II: FOREWARNING METHOD

\begin{tabular}{|c|c|}
\hline $\begin{array}{c}\text { Forewarning } \\
\text { type }\end{array}$ & Forewarning method \\
\hline $\begin{array}{l}\text { Academic } \\
\text { credit }\end{array}$ & $\begin{array}{l}\text { 1. List based on subjects and classes to inquire } \\
\text { 2. Forewarning e-mails are sent by inform-ation } \\
\text { system and e-mails can be resent repeatedly. } \\
\text { 3.The process of sending forewarning e-mails will be } \\
\text { recorded. }\end{array}$ \\
\hline Score & $\begin{array}{l}\text { 1.The } 5 \% \text { of students in the class from the last in the } \\
\text { first or second midterm exams will receive } \\
\text { forewarning e-mails. } \\
\text { 2.If the mean scores of subjects are below } 50 \text { scores in } \\
\text { the first or second midterm exams, forewarning } \\
\text { e-mails will be sent to subject teachers. } \\
\text { 3.Forewarning e-mails are sent by information system } \\
\text { and e-mails can be resent repeatedly. } \\
\text { 4. The process of sending forewarning e-mails will be } \\
\text { recorded. } \\
\text { 5. Subject teachers who receive forewarning e-mails } \\
\text { need to reorganize their instruction plan to improve } \\
\text { students' learning achievement. }\end{array}$ \\
\hline $\begin{array}{l}\text { Behavioral } \\
\text { Performance } \\
\text { (Rewarding, } \\
\text { punishment } \\
\text { and absence } \\
\text { conditions) }\end{array}$ & $\begin{array}{l}\text { 1. Students who receive } 18 \text { or } 27 \text { times of warning for } \\
\text { their behavioral performance will be listed based on } \\
\text { classes and departments to inquire. } \\
\text { 2. The hours that students who are absent, late, early } \\
\text { leaving from class are more than } 21 \text {. They will be } \\
\text { forewarned. } \\
\text { 3.Forewarning e-mails are sent by information system } \\
\text { and e-mails can be resent repeatedly. } \\
\text { 4.The process of sending forewarning e-mails will be } \\
\text { recorded }\end{array}$ \\
\hline
\end{tabular}

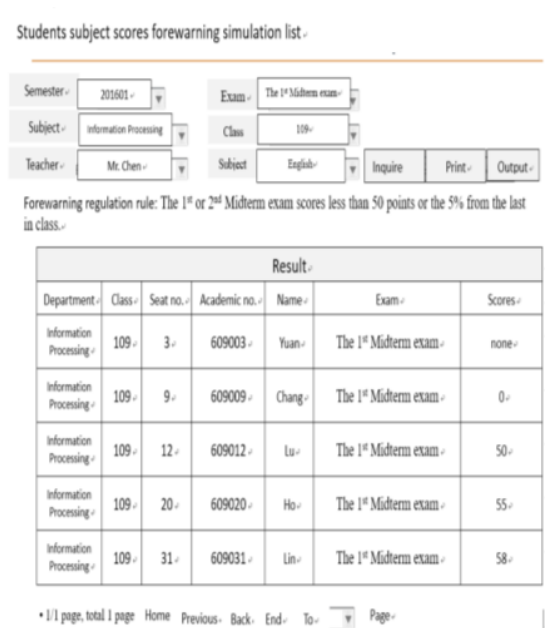

Fig. 12. Students subject scores forewarning simulation list.

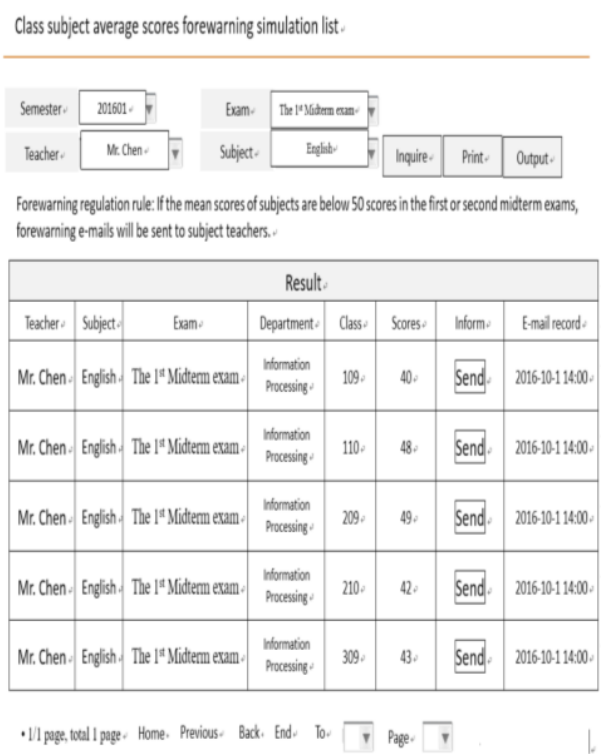

Fig. 13. Class subject average scores forewarning simulation list. 


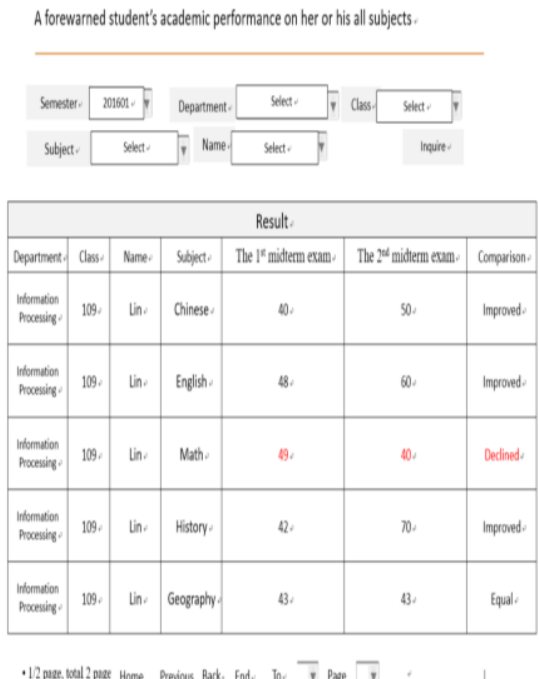

Fig. 14. A forewarned student's academic performance on her or his all subjects.
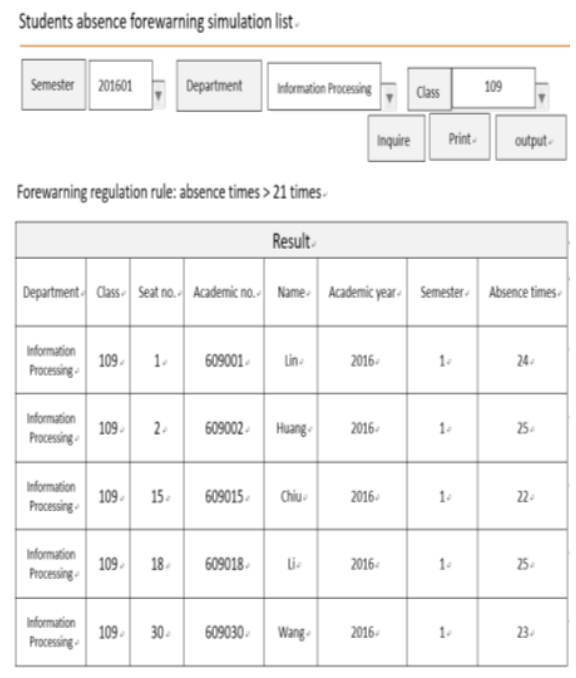

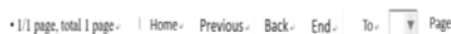

Fig. 15. Students absence forewarning simulation list

\section{CONClusion ANd SugGestion}

In Taiwan, forewarning system based on IR, preventing and warning in advance, can help to understand the students' poor adaptation and performance in academic or life areas in time. Its greatest function and value are that students themselves, teachers and administrators can perceive the declining situation before it become worse and worse. Although the study was conducted within the context of Taiwanese education system, the experiences of applying both IR and forewarning activated by information systems in senior high schools to realize evidenced-based school affairs decisions-making or improve students' academically and behaviorally performance could be beneficial transnationally and cross-culturally.

Some suggestions for the empirical work of schools and the future researches are mentioned as follows.

1) The follow-up instruction and counseling measures for the forewarned students will be the key to the stability of students' learning and behavioral performance. Schools need to stress the importance of the improvement programs or plans to upgrade students' performance.
2) How to confirm or evaluate the effectiveness of the improvement programs or plans proposed by the forewarned teachers? The establishment of an instructional team was suggested to offer counseling mechanism to assist the forewarned teachers. Assessing students' learning characteristics, designing instructional materials well, and students' counseling and evaluation works are all necessary action to take for those forewarned students. The improvement of forewarned teachers' work can also be considered to include in the evaluation of teachers' performance evaluation.

3) As forewarning system is introduced after a school year, schools may consider to survey the users' experience by a qualitative or quantitative research. The results of the survey will be used to improve the effectiveness of the forewarning system.

\section{REFERENCES}

[1] J. Aper, "Higher education and the state: Accountability and the roots of student outcomes assessment," Higher Education Management, vol. 5, pp. 336-376, 1993.

[2] P. Ewell, "Strengthening assessment for academic quality improvement," Planning and Management for a Changing Environment: A Handbook on Redesigning Postsecondary Institutions, San Francisco: Jossey Bass, 1997.

[3] P. Ewell, "An emerging scholarship: A brief history of assessment," Building a Scholarship of Assessment, San Francisco: Jossey Bass, pp. 3-25, 2002.

[4] K. L. Webber, "The role of institutional research in a high profile study of undergraduate research," Res High Educ., 2012, vol. 53, pp. 695-716, 2012.

[5] C.-T. Tsai, "Focus topic: Taiwan's first institutional research professional organization was established," Journal of Evaluation Bimonthly, p. 60, 2016.

[6] Ministry of Education. (2016). Senior High School Education Act. [Online] Available: http://law.moj.gov.tw/Eng/LawClass/LawContent.aspx?PCODE=H00 60043

[7] Senior high school evaluation (2015). The third stage of Senior high school evaluation programs: Ordinary senior high schools, bilateral high schools, magnet senior high schools. [Online] Available: http://qoi.nknu.edu.tw/TeachingEva/User/NewsData.aspx?newno=d1 8b8312-108a-4d1c-bbb2-8378fcc8add2

[8] Taiwan Normal University. (2012). Resources - institutional research feedback teaching. [Online]. Available: http://211.72.214.242/ote/subplan.php?sn=21

[9] D.-I. Jiang, "The advent of the institutional research era," Journal of Evaluation Bimonthly, p. 60, 2016.

[10] F. Volkwein, "Teaching and learning in IR courses: Myths vs. reality," presented at the Forum of the Association for Institutional Research, Denver, CO, 2015

[11] K. Webber et al., "IR in the world around us," presented at the Forum of the association for Institutional Research, Denver, CO, 2015.

[12] S.-F. Lin and Y.-J. Lin, "The application of institutional research in a senior high school of Taiwan," presented at ECBA-2016, 2016.

[13] S.-F. Lin, Y.-J. Lin, and C.-L. Wu, "An empirical study of institutional research in a senior high school," presented at BESSH-2016, 2016.

[14] Visual Intelligence. (2016). Qlik Business Intelligence Experts. [Online]. Available: http://www. bilab. pro/bi/_Slides/BI.pptx

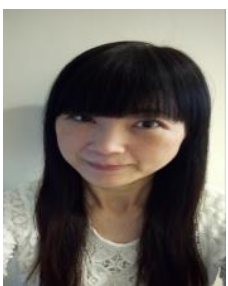

Shu-Fang Lin was born in Yun-Lin, Taiwan. She is currently a $\mathrm{PhD}$ student at the Department of Educational Policy and Administration of National Chi Nan University Taiwan since 2015. She is also a teacher in the Affiliated Senior High School of National Chi Nan University Taiwan. 


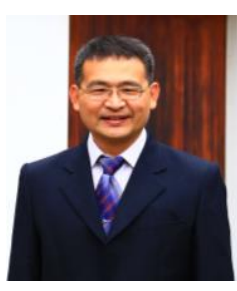

Hung-Chang Chang was born in Changhua, Taiwan. He is a $\mathrm{PhD}$ student at the Department of Educational Policy and Administration of National Chi Nan University Taiwan. He is also a principal of Changhua County Ping He Elementary School Taiwan.

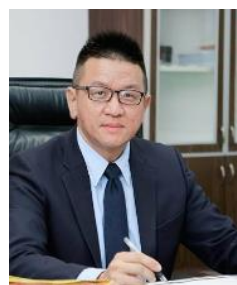

Chi Tung Chen was born in Taichung, Taiwan. He is now an associated professor at the Center for General Education of National Chi Nan University Taiwan. He is also a principal of the Affiliated High School of National Chengchi University Taiwan.
Ching Ling Wu was born in Changhua, Taiwan. She is currently a professor at the Department of Educational Policy and Administration of National Chi Nan University Taiwan. She is proficient in College educational experiences and student outcomes. 